\title{
PENGEMBANGAN LEMBAR KERJA SISWA DENGAN PENDEKATAN REALISTIC MATHEMATIC EDUCATION BERBANTUAN BAKER APPLET UNTUK MENINGKATKAN KEMAMPUAN PEMAHAMAN KONSEP PERSAMAAN LINIER SATU VARIABEL SISWA KELAS VIII SMP NEGERI 3 BINJAI TAHUN PELAJARAN 2018/2019
}

\author{
Sri Wahyuni \\ STKIP Budidaya Binjai Sumatera Utara \\ yuni210984@gmail.com
}

Dibiayai oleh :

Direktorat Riset dan Pengabdian Masyarakat

Direktorat Jenderal Penguatan Riset dan Pengembangan

Kementerian Riset, Teknologi dan Pendidikan Tinggi

Sesuai dengan Kontrak Penelitian Tahun Anggaran 2019

\begin{abstract}
ABSTRAK
Penelitian ini adalah jenis penelitian pengembangan yang bertujuan untuk : (1) Mengukur efektivitas Lembar Kerja Siswa (LKS) dengan pendekatan Realistic Mathematic Education berbantuan Baker Applet yang dikembangkan, dan (2) Mengetahui peningkatan kemampuan pemahaman konsep persamaan linear satu variabel pada ujicoba I ke ujicoba II dengan menggunakan perangkat pembelajaran pendekatan Realistic Mathematic Education berbantuan Baker Applet yang telah dikembangkan. Model pengembangan yang digunakan dalam penelitian yaitu model 4-D yang terdiri dari 4 tahap, yaitu tahap pendefinisian (define), tahap perencanaan (design), tahap pengembangan (develop) dan tahap penyebaran (disseminate). Untuk tahap penyebaran dilakukan penyebaran terbatas. Hasil pengembangan diterapkan terbatas pada sekolah mitra saja, yaitu SMP Negeri 3 Binjai. Instrumen penelitian berupa tes pemahaman konsep persamaan linier satu variabel siswa, lembar pengamatan aktivits siswa dan angket respon siswa. Dari hasil pengembangan ini diperoleh hasil : (1) Lembar Kerja Siswa dengan pendekatan Realistic Mathematic Education berbantuan Baker Applet yang dikembangkan valid dan efektif (2) Kemampuan pemahaman konsep persamaan linier satu variabel siswa yang menggunakan LKS yang dikembangkan berdasarkan hasil uji lapangan yang dilakukan telah tercapai dan meningkat.
\end{abstract}

Kata kunci: Lembar Kerja Siswa, Baker Applet, Persamaan Linier Satu Variabel

\section{ABSTRACT}

This research is a type of development research that aims to: (1) Measure the effectiveness of student worksheets with Baker Applet's Realistic Mathematic Education approach that developed, and (2) Knowing the increase in the ability to understand the concept of a one-variable linear equation in the first trial to the second trial by using the learning tool of the Baker Applet assisted Realistic Mathematic Education approach that has been developed. The development model used in the study is the 4-D model which consists of 4 stages, namely the defining stage, the planning stage, the development stage and the disseminate stage. For the deployment phase, the distribution is limited. The results of the development are limited to partner schools, namely SMP Negeri 3 Binjai. The research instrument was in the form of an understanding test of the concept of linear equations of one variable of students, an observation sheet of student activity and a student questionnaire response. From the results of this development results are obtained: (1) Student worksheets with Baker Applet-assisted Realistic Mathematic Education approach developed are valid and effective (2) The ability to understand the concept of linear equations of one variable of students using student worksheet which was developed based on the results of field tests conducted has been achieved and increase. 


\section{PENDAHULUAN}

Kemampuan pemahaman konsep merupakan salah satu kecakapan atau kemampuan matematika yang sangat penting dalam mencapai tujuan pembelajaran matematika. Pemahaman konsep yang baik akan turut mempengaruhi daya matematika siswa, jika siswa dapat memahami konsep matematika dengan baik, maka siswa dapat menganalisa permasalahan dan mampu untuk menyelesaikan masalahnya.

Namun kenyataan di lapangan menunjukkan adanya kesenjangan yang sangat jauh antara tujuan pembelajaran matematika dengan hasil belajar matematika siswa di sekolah. Hal ini juga terjadi di lingkungan SMP Negeri 3 Binjai. Hal ini diperkuat dengan pengamatan peneliti dan hasil diskusi dengan teman sejawat sesama guru matematika di SMP Negeri 3 Binjai bahwa kemampuan konsep siswa pada materi persamaan linier satu variabel sangat rendah. Mereka menyatakan bahwa siswa sangat kesulitan mempelajari materi tersebut karena konsep persamaan linier satu variabel sangat rendah bahkan ada yang salah konsep karena banyak menggunakan istilah "pindah ruas". Hal tersebut diatas dapat terjadi karena memang siswa tidak memaknai apa sebenarnya arti persamaan, atau guru hanya mengajarkan materi persamaan linier satu variabel dengan latihan-latihan tanpa tau bagaimana konsep itu bekerja. Artinya pembelajaran yang dilaksanakan tidak bermakna karena siswa hanya bersikap pasif dan hanya menerima tanpa pernah mengeksplor kemampuan siswa itu sendiri, akibatnya pembelajaran itu mudah dilupakan atau tidak bermakna.

Untuk mengatasi hal tersebut diatas sebagai salah satu alternatif pembelajaran yang sangat baik untuk meningkatkan pemahaman konsep siswa pada materi persamaan linier satu variabel ini adalah pembelajaran dengan pendekatan Realistic Mathematic Education (RME). Sesuai dengan konsep $R M E$ yang disebutkan Freudenthal (dalam Wijaya: 2012:
20) bahwa proses belajar siswa hanya akan terjadi jika pengetahuan (knowledge) yang dipelajari bermakna bagi siswa.

Utrecth University sebagai pusat pembelajaran Realistic Mathematic Education $(R M E)$ mengembangkan suatu aplikasi online untuk membantu pembelajaran matematika sekolah yang di kenal dengan aplikasi Applet. Aplikasi ini sangat menarik untuk diberikan kepada siswa kelas VIII SMP karena pada aplikasi pada materi ini siswa diajak untuk mengenal arti persamaan yang dikaitkan dengan kehidupan sehari-hari. Selain itu pada aplikasi ini siswa seperti diajak bermain karena aplikasi ini berbentuk aplikasi interaktif. Jadi siswa dapat memainkan timbangan untuk membuat keseimbangan yang nantinya menguatkan konsep persamaan yang sebenarnya. Hal ini juga sangat sesuai dengan salah satu pembeda pembelajaran kurikulum 2013 revisi tahun 2016 dengan pembelajaran kurikulum 2013 revisi tahun 2017 yang salah satunya adalah megintegrasikan literasi dan menginsert literasi dalam pembelajaran baik sebelum, sedang dan sesudah pembelajaran. Dalam hal ini literasi yang dimunculkan adalah literasi teknologi.

Namun karena kurangnya fasilitas komputer dan internet di SMP Negeri 3 Binjai, maka guru sebagai peneliti memodifikasi aplikasi- aplikasi tersebut dalam bentuk lembar kerja. Lembar kerja ini selanjutnya diberi nama Baker Applet yang merupakan akronim dari lembar kerja Applet. Gambar-gambar nya diambil dan diinovasi dari aplikasi APPLET. Lembar kerja tersebut juga sesuai dengan mengintegrasikan literasi visual dalam pembelajaran. Diharapkan setelah anak-anak mahir menyelesaikan lembar kerja yang diberikan, siswa akan mengkonstruksi konsep persamaan linier satu variabel dengan pengetahuannya sendiri karena mereka tidak "diajarkan" dan yang pasti lebih menyenangkan karena siswa seperti diajak bermain dengan objek yang berwarna-warni yang sangat 
menarik dan dibimbing dari matematika yang sangat nyata, kemudian semi formal dan

\section{METODOLOGI PENELITIAN}

Penelitian ini termasuk penelitian pengembangan (Developmental Research). Penelitian dilaksanakan di SMP Negeri 3 Binjai. Subjek dalam penelitian ini adalah siswa kelas VIII SMP Negeri 3 Binjai dan objek dalam penelitian ini adalah pengembangan lembar kerja siswa dengan pendekatan pendekatan Realistic Mathematic Education berbantuan Baker Applet.

Pengembangan lembar kerja siswa dalam penelitian ini mengacu pada model pengembangan menurut Thiagarajan, Semmel dan Semmel, yaitu model 4-D (four D models) yang terdiri dari 4 tahap, yaitu (1) tahap pendefinisian (define), Tujuan tahap pendefinisian ialah untuk menetapkan dan mendefinisikan syarat-syarat pembelajaran yang terdiri atas 5 langkah pokok yaitu analisis awal akhir, analisis siswa, analisis tugas, analisis konsep, dan spesifikasi indikator pembelajaran, (2) tahap perencanaan (design), Dalam tahap ini dilakukan penyusunan perangkat meliputi: penyusunan tes, pemilihan media dan pemilihan format, sehingga diperoleh Draft A, (3) tahap pengembangan (develop), pada tahap pengembangan memiliki tujuan untuk menghasilkan Draft B perangkat pembelajaran yang telah direvisi berdasarkan akhirnya matematika formal.

masukan para ahli dan data yang diperoleh dari uji coba. Kegiatan pada tahap ini adalah penilaian para ahli dan uji coba lapangan, (4) tahap penyebaran (disseminate). Untuk tahap penyebaran dilakukan penyebaran terbatas. Hasil pengembangan diterapkan terbatas pada sekolah mitra saja, yaitu di SMP Negeri 3 Binjai.

Instrumen penelitian dan teknik pengumpulan data disusun untuk mengukur kevalidan dan efektivitas lembar kerja siswa dengan pendekatan pendekatan Realistic Mathematic Education berbantuan Baker Applet. Instrumen yang digunakan dalam penelitian ini adalah (1) lembar validasi yaitu validasi LKS (Lembar Kerja Siswa) dan validasi tes kemampuan pemahaman konsep persamaan linier satu variabel siswa, (2) lembar pengamatan aktivitas siswa, (3) angket respon siswa. Teknik analisis data yang digunakan dalam penelitian ini adalah analisis statistik deskriptif. Rancangan uji coba yang akan digunakan dalam penelitian ini adalah one-shot case study atau disebut juga dengan one-group posttest-only design (Setyosari, 2012: 174).

Tabel 1. Hasil Validasi Lembar Kerja Siswa

\begin{tabular}{|c|c|c|c|}
\hline No & \multicolumn{1}{|c|}{ Aspek yang dinilai } & Rata-rata & Kategori \\
\hline I & FORMAT & 4,00 & Valid \\
\hline & a. Kejelasan pembagian materi & 4,20 & Valid \\
\hline & b. Menarik & 4,00 & Valid \\
\hline & c. Sistem penomoran jelas & 4,40 & Valid \\
\hline & d. Pengaturan ruang/tata letak & 4,60 & Valid \\
\hline & e. Jenis dan ukuran huruf sesuai & 4,40 & Valid \\
\hline & f. Kesesuaian antara fisik LKS dengan siswa & 4,60 & Valid \\
\hline II & BAHASA & 4,00 & Valid \\
\hline & $1 . \quad$ Kebenaran tata bahasa & \\
\hline & $\begin{array}{l}\text { Kesesuaian kalimat dengan taraf berpikir dan } \\
\text { kemampuan membaca serta usia siswa }\end{array}$ & 4,20 & Valid \\
\hline & 3. Mendorong minat untuk bekerja & 4,20 & Valid \\
\hline
\end{tabular}




\begin{tabular}{|c|c|c|c|}
\hline No & Aspek yang dinilai & Rata-rata & Kategori \\
\hline & 5. Kalimat soal tidak mengandung arti ganda & 4,40 & Valid \\
\hline & 6. Kejelasan petunjuk dan arahan & 4,60 & Valid \\
\hline & 7. Sifat komunikatif bahasa yang digunakan & 4,20 & Valid \\
\hline \multirow[t]{9}{*}{ III } & ISI & & \\
\hline & 1. Kebenaran isi/materi & 4,20 & Valid \\
\hline & 2. Merupakan materi/tugas yang esensial & 4,20 & Valid \\
\hline & 3. Dikelompokkan dalam bagian-bagian yang logis & 4,40 & Valid \\
\hline & $\begin{array}{l}\text { 4. } \begin{array}{l}\text { Kesesuaian dengan pendekatan Realistic } \\
\text { Mathematic Education }\end{array} \\
\end{array}$ & 4,00 & Valid \\
\hline & 5. $\quad$ Kesesuaian dengan urutan materi & 4,20 & Valid \\
\hline & $\begin{array}{l}\text { 6. Peranannya mendorong siswa dalam menemukan } \\
\text { konsep/prosedur untuk secara mandiri }\end{array}$ & 4,20 & Valid \\
\hline & 7. Kelayakan sebagai perangkat pembelajaran & 4,20 & Valid \\
\hline & Rata-rata & 4,26 & Valid \\
\hline
\end{tabular}

Rata-rata skor masing-masing aspek penilaian dari kelima validator adalah lebih besar atau sama dengan $4(\geq 4,0)$ dengan kriteria "valid". Rata-rata skor seluruhnya terhadap penilaian LKS berada pada kriteria valid, yaitu sebesar 4,31. Efektivitas lembar kerja siswa matematika yang dikembangkan berbasis pendekatan Realistic Mathematic Education berbantuan Baker Applet untuk meningkatkan kemampuan pemahaman konsep persamaan linier satu variabel siswa dicapai pada 3 indikator yaitu ; respon siswa, persentase waktu ideal aktivitas siswa dan ketuntasan belajar siswa secara klasikal pada ujicoba LKS. Persentase respon siswa dan aktivitas siswa dihitung dengan menggunakan rumus yaitu Proporsional siswa yang memilih dibagi Jumlah siswa (responden) dikali $100 \%$ (Trianto, 2011:243). Kriterianya adalah jika $80 \%$ atau lebih siswa merespon dalam kategori positif maka respon siswa dikatakan positif. Persentase aktivitas siswa (P) yaitu frekuensi setiap aspek pengamatan dibagi dengan jumlah frekuensi semua aspek pengamatan dikali 100 $\%$. Ketuntasan belajar siswa dapat dianalisis dengan cara membandingkan rata-rata skor siswa yang diperoleh dari hasil tes uji coba. Siswa dapat dikatakan tuntas apabila nilai siswa secara individual mencapai 2,67. Selanjutnya, suatu pembelajaran dikatakan telah tuntas secara klasikal yaitu terdapat $85 \%$ siswa yang mengikuti tes telah mencapai skor minimal 2,67 (Permendikbud, 2014).

\section{HASIL DAN PEMBAHASAN}

Penelitian ini adalah penelitian pengembangan (developmental research) sehingga produk dari penelitian ini adalah Lembar Kerja Siswa (LKS) dengan pendekatan Realistic Mathematic Education berbantuan Baker Applet yang memenuhi kriteria valid dan efektif untuk meningkatkan kemampuan pemahaman konsep persamaan linier satu variabel siswa. Dalam proses pengembangan untuk mendapatkan LKS yang valid dan efektif, dilakukan kegiatan uji coba dengan menggunakan LKS yang telah disusun dan dikembangkan serta instrument-instrumen sebagai alat ukur keefektifan LKS. Ujicoba dilakukan sebanyak dua kali yaitu pada kelas VIII SMP Negeri 3 Binjai. Pembelajaran menggunakan LKS yang dikembangkan pada kelas ini dilakukan sebanyak 4 kali pertemuan pada ujicoba I dan 4 kali pertemuan pada ujicoba II. Hasil analisis data pada ujicoba I diperoleh LKS dengan pendekatan Realistic Mathematic Education berbantuan Baker Applet yang valid tetapi belum efektif seluruh komponennya, yaitu pada ketuntasan belajar klasikal yang belum tercapai dan beberapa aktivitas siswa yang belum berada pada batas toleransi yang ideal. Peningkatan kemampuan pemahaman konsep persamaan linier satu variabel siswa pada hasil posttest pada ujicoba I dan ujicoba II dapat dilihat pada Tabel 2 berikut: 
Tabel 2. Peningkatan Kemampuan Pemahaman Konsep Persamaan Linier Satu Variabel

\begin{tabular}{|c|c|}
\hline Posttest & Ketuntasan Belajar (Klasikal) \\
\hline Uji Coba I & $72,50 \%$ \\
\hline Uji Coba II & $89,85 \%$ \\
\hline
\end{tabular}

Berdasarkan Tabel 2 tersebut menunjukkan bahwa persentase siswa yang telah memiliki ketuntasan belajar dari hasil Uji Coba I dan Uji Coba II pada materi persamaan linier satu variabel pada hasil posttest mengalami peningkatan sebesar $17,35 \%$.

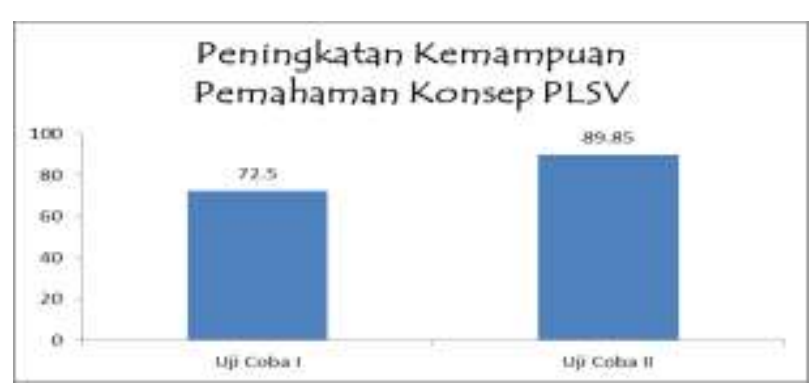

Gambar 1. Peningkatan Kemampuan Pemahaman Konsep PLSV Siswa

Secara keseluruhan rerata persentase waktu yang digunakan siswa dalam melakukan kategori aktivitas dapat direpresentasikan dengan diagram pada gambar 2 berikut:

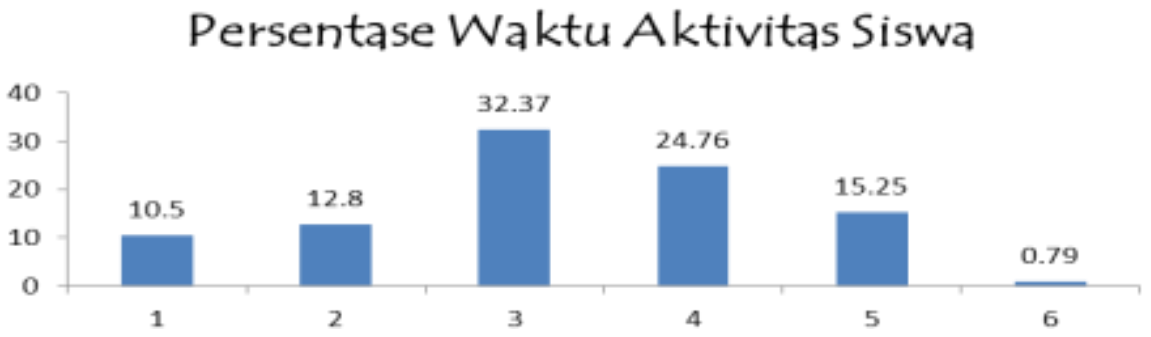

Gambar 2. Diagram Persentase Aktivitas Siswa pada Uji coba II

Jika rerata persentase waktu aktivitas siswa masing-masing kategori dirujuk pada kriteria penentuan ketercapaian persentase waktu ideal aktivitas siswa, maka dapat disimpulkan bahwa persentase waktu aktivitas siswa memenuhi pencapaian persentase waktu ideal atau berada pada interval toleransi waktu kategori aktivitas siswa yang ditetapkan. Hasil analisis data respon siswa terhadap komponen dan kegiatan pembelajaran disajikan pada tabel 3 berikut:

Tabel 3. Hasil Angket Respon Siswa Uji Coba II

\begin{tabular}{|c|c|c|c|}
\hline \multirow{2}{*}{ No } & \multirow{2}{*}{ Aspek yang direspon } & \multicolumn{2}{|c|}{ Persentase (\%) } \\
\hline & & Jelas & Tidak Jelas \\
\hline \multirow[t]{5}{*}{1.} & Perasaan siswa terhadap komponen pembelajaran & & \\
\hline & a. $\quad$ Materi ajar & 92 & 8 \\
\hline & b. Lembar Kerja Siswa & 93 & 7 \\
\hline & c. Suasana pembelajaran di kelas & 90 & 10 \\
\hline & d. $\quad$ Cara guru mengajar & 91 & 9 \\
\hline & & Baru & Tidak Baru \\
\hline \multirow[t]{3}{*}{2.} & Pendapat siswa terhadap komponen pembelajaran : & & \\
\hline & a. $\quad$ Materi ajar & 90 & 10 \\
\hline & b. Lembar Kerja Siswa & 100 & 0 \\
\hline
\end{tabular}




\begin{tabular}{|c|c|c|c|}
\hline No & \multicolumn{1}{|c|}{ Aspek yang direspon } & \multicolumn{2}{c|}{ Persentase (\%) } \\
\cline { 2 - 4 } & c. Suasana pembelajaran di kelas & 92 & 8 \\
\cline { 2 - 4 } & d. Cara guru mengajar & Berminat & Tidak Berminat \\
\hline \multicolumn{1}{|l|}{3.} & $\begin{array}{l}\text { Pendapat siswa tentang minat untuk mengikuti } \\
\text { pelajaran selanjutnya dengan pendekatan Realistic } \\
\text { Mathematic Education }\end{array}$ & 92 & 8 \\
\hline \multicolumn{2}{|l|}{$\begin{array}{l}\text { Pendapat siswa tentang pemahaman bahasa yang } \\
\text { digunakan dalam Lembar Kerja Siswa }\end{array}$} & 92 & Telas \\
\hline \multicolumn{2}{|l|}{$\begin{array}{l}\text { Pendapat siswa tentang penampilan (tulisan, } \\
\text { illustrasi/gambar dan letak gambar) yang ada dalam } \\
\text { Lembar Kerja Siswa }\end{array}$} & 90 & Tidak Tertarik \\
\hline
\end{tabular}

Dari data di atas, dapat dianalisis bahwa respon siswa terhadap semua aspek LKS berada di atas $80 \%$. Jika hasil analisis ini dirujuk pada kriteria yang ditetapkan, dapat disimpulkan bahwa respon siswa terhadap Lembar Kerja Siswa (LKS) dengan pendekatan Realistic Mathematic Education berbantuan Baker Applet adalah positif. Hasil analisis data ujicoba II adalah sebagai berikut: (1) terdapat peningkatan kemampuan pemahaman konsep persamaan linier satu variabel siswa; (2) kadar aktivitas aktif siswa mencapai kriteria keefektifan; (3) angket respon siswa pada setiap komponen dan kegiatan pembelajaran adalah positif. Jika kesimpulan hasil analisis data pada ujicoba II ini dirujuk pada kriteria yang ditetapkan, maka dapat disimpulkan bahwa penerapan produk LKS dengan pendekatan Realistic Mathematic Education berbantuan Baker Applet yang dikembangkan telah memenuhi kriteria keefektifan. Berdasarkan hasil penilaian ahli serta kesimpulan hasil analisis data pada ujicoba, semua aspek yang ditentukan untuk menyatakan sebuah produk pengembangan LKS adalah valid dan efektif sudah dipenuhi, maka ujicoba pengembangan untuk mendapatkan LKS valid dan efektif telah selesai.

\section{SIMPULAN DAN SARAN}

Berdasarkan pengembangan perangkat pembelajaran dengan menggunakan model 4-D yang telah dimodifikasi, dihasilkan Lembar Kerja Siswa (LKS) dengan pendekatan
Realistic Mathematic Education berbantuan Baker Applet yang valid dan efektif secara keseluruhan untuk siswa kelas VIII. Berdasarkan simpulan penelitian di atas, pembelajaran dengan pendekatan Realistic Mathematic Education dengan menggunakan lembar kerja siswa berbantuan Baker Applet yang diterapkan pada kegiatan pembelajaran memberikan beberapa hal yang penting untuk diperhatikan. Untuk itu peneliti menyarankan beberapa hal sebagai berikut: (1) Lembar Kerja Siswa yang dihasilkan ini baru sampai pada tahap penyebaran terbatas yaitu hanya di SMP Negeri 3 Binjai, belum diimplementasikan secara luas di sekolah-sekolah, (2) Untuk mengetahui efektivitas lembar kerja siswa dengan pendekatan Realistic Mathematic Education berbantuan Baker Applet dalam berbagai topik pelajaran matematika dan mata pelajaran lain yang sesuai, disarankan pada para guru dan peneliti untuk mengimplementasikan lembar kerja siswa dengan pendekatan Realistic Mathematic Education ini pada ruang lingkup yang lebih luas di sekolah-sekolah.

\section{DAFTAR PUSTAKA}

Arends. (2008). Learning to Teach, Belajar untuk Mengajar. Edisi Ketujuh. Jilid Dua. (diterjemahkan oleh Soedjipto, Helly, P. dan Soedjipto, Sri, M.) Yogyakarta: Pustaka Pelajar

Febriyani. (2015). Pengembangan Perangkat Pembelajaran Berbasis Pendekatan 
Matematika Realistik Untuk Meningkatkan Kemampuan Pemahaman Konsep dan Disposisi Matematis Siswa MTs $N$ Tanjung Pura.Unimed

Jupri, A., Drijvers, P. \& Van den Panhuizen, M. (2015). Improving Grade 7 Students' Achievement in Initial Algebra Trough a Technology-Based Intervention: Published Online
Setyosari. (2010). Metode Penelitian

Pendidikan dan Pengembangan.

Jakarta: Prenada Mediagroup

Trianto. (2011). Mendesain Model Pembelajaran Inovatif Progresif. Jakarta: Kencana Prenada Media Group. Wijaya, A. (2012). Pendidikan Matematika Realistik Suatu Alternatif Pendekatan Pembelajaran Matematika. Yogyakarta: Graha Ilmu. 